\title{
PERMASALAHAN GURU BAHASA INGGRIS DALAM MENGIMPLEMENTASIKAN KURIKULUM 2013 DI SLTA KABUPATEN TANAH DATAR
}

\author{
Suswati Hendriani \\ Program Studi Tadris Bahasa Inggris, Jurusan Tarbiyah STAIN Batusangkar \\ Korespondensi: Perumahan Arai Pinang I Blok i No.6 Kuburajo, Lima Kaum, \\ Batusangkar, Sumatera Barat \\ e-mail: suswatiamor@gmail.com
}

\begin{abstract}
The research is conducted based on the fact that Senior high school English teachers of Tanah Datar Regency face problems in implementing curiculum 2013.The research is aimed at finding out the problems of the teachers related to the implementation of the Curriculum. Therefore, a qualitative research method was applied. To collect the data of the research, interview technique was used. To analyze the colled data, interactive model of analysis as proposed by Miles and Huberman was used. The results of the research show that there were two types of the problems that the teachers faced in implementing the new Curriculum, those deriving from the teachers themsevels, and those deriving from others, like government, students and facilities.
\end{abstract}

Kata kunci: permasalahan, guru, bahasa Inggris, implementasi, kurikulum 2013

\section{PENDAHULUAN}

$\mathrm{T}$ lingkat peradaban dan karakter suatu bangsa amat ditentukan oleh keberhasilan dunia pendidikan. Untuk melahirkan bangsa yang berkarakter, maka pendidikan yang dijalankan hendaknya mengajarkan nilainilai karakter. Karakter adalah "cara berpikir dan berperilaku yang khas tiap individu untuk hidup dan bekerja sama, baik dalam lingkup keluarga, masyarakat, bangsa dan negara" (Samani dan Hariyanto, 2013: 40). Rajasa dalam Muslich (2011) menyatakan ada hal yang prinsip dalam rangka pembinaan karakter bangsa, yaitu: (1) Pendidikan sebagai arena untuk melakukan reaktivasi karakter luhur bangsa Indonesia, (2) Pendidikan sebagai sarana untuk membangkitkan karakter bangsa untuk percepatan pembangunan dan mobilisasi potensi domestic untuk meningkatkan daya saing bangsa; dan (3) Pendidikan sebagai sarana menginternalisasi kedua aspek di atas. Lebih lanjut, Samani dan Hariyanto (2013: 40) mengatakan bahwa pendidikan karakter pada prinsipnya memiliki tiga fungsi, yaitu: (1) memberikan sosialisasi tentang esensi nilainilai budaya kepada peserta didik tentang perlunya tanggung jawab moral; (2) membantu peserta didik menguasai keterampilan membaca, menulis dan berhitung serta keterampilan yang yang diperlukan dalam dunia kerja, dan (3) memberi arahan kepada peserta didik agar mampu menempatkan dirinya seara tepat dan sepadan di masyarakat. Untuk mewujudkan prinsip-prinsip dimaksud, guru memegang peranan yang 
sangat penting. Dengan kata lain, guru adalah kunci keberhasilan dalam pelaksanaan pendidikan sebagai bentuk implementasi Kurikulum Berbasis Karakter atau Kurikulum 2013.

Di Indonesia, proses pendidikan yang dilakukan oleh guru juga harus disesuaikan dengan kurikulum yang berlaku, yaitu Kurikulum 2013. Peran guru menurut kurikulum baru ini juga berubah baik dalam proses pembelajaran, jumlah mata pelajaran dan jumlah jam pelajaran. Agar pendidikan karakter berhasil dengan baik dibutuhkan guru yang berkualitas yang mampu menerapkan Kurikulum 2013 ini, yang difokuskan pada ketiga perubahan tersebut. Pertama, peningkatan kualitas guru dalam proses pembelajaran yang menekankan aspek kognitif, afektif, psikomotorik melalui penilaian berbasis tes dan portofolio. Berarti dalam pembelajaran, guru harus bisa meningkatkan ketiga aspek tersebut supaya siswa bisa lebih aktif dalam proses pembelajaran. Kedua, penigkatan kualitas guru dalam perubahan jumlah mata pelajaran. Ketiga, peningkatan kualitas guru dalam perubahan jumlah jam pelajaran, yang mana dalam Kurikulum 2013 alokasi waktu per jam pelajaran untuk SD 35 menit, SMP 40 menit dan SMA 45 menit (http://writingcontest.bisnis.com/artikel /read/ 20140401/377/ 215082/ peningkatankualitas-guru-untuk-menyeimbangkandengan-kurikulum- 2013-dalam membangun-pendidikan-di-indonesia yang diunduh pada Jumat, 9 Mei 2014).

Walaupun pada tahun ini Kurikulum 2013 harus diterapkan secara menyeluruh, namun dari data dan pantauan di lapangan ternyata kesiapan untuk implementasi Kurikulum 2013 ini masih jauh dari yang diharapkan. Guru sebagai jantung pendidikan yang menjadi ujung tombak keberhasilan implementasi Kurikulum 2013, ternyata sangat sedikit yang telah dilatih untuk implementasi Kurikulum ini. Artinya, baru sebagian kecil guru yang bisa dianggap berkualitas dalam rangka implementasi kurikulum baru ini. Dari hasil survey tentang pelaksanaan Kurikulum Berbasis Karakter (Kurikulum 2013) terhadap 200 guru di kota Bogor pada bulan September 2013 terungkap bahwa: 1) $60 \%$ guru belum ikut sosialisasi kurikulum 2013; 2) $71 \%$ tidak mengerti pembelajaran yang sesuai kurikulum 2013; 74\% tidak tahu bagaimana evaluasi pembelajaran kurikulum 2013, dan 4) $11,3 \%$ guru tidak pernah dilibatkan dalam perbaikan kurikulum. (B.A. dalam http://www.unpak.ac.id/ index.php/15-news/91-seminar-nasionalimplementasi-kurikulum-2013-gurusekolah-dasar). Fakta yang senada diungkapkan oleh Dr.Unifah Rosyidi, M.Pd, yang mengatakan: dari 2,9 juta guru yang ada di Indonesia, baru 50.000 guru yang telah mendapatkan pelatihan kurikulum 2013.

(http://www.unpak.ac.id/index.php/15news/91-seminar-nasional-

implementasi-kurikulum-2013-gurusekolah-dasar).

Berdasarkan data tersebut, terlihat bahwa implementasi kurikulum baru ini kelihatannya akan menuai masalah. Kondisi yang sama juga terjadi di Kabupaten Tanah Datar. Dari survei pendahuluan yang telah dilakukan terungkap bahwa untuk Kabupaten Tanah Datar baru tiga sekolah yang berhak menerapkan Kurikulum 2013 yaitu SMAN 1 Batusangkar, SMAN 2 Batusangkar dan SMAN 1 Lintau Buo (Sumber: Dinas Pendidikan Kabupaten Tanah Datar). Ketiga sekolah ini menjadi pilot project bagi implementasi Kurikulum 2013 di Kabupaten Tanah Datar. Padahal pendidkan karakter sudah mendesak untuk diimplementasikan agar karakter generasi muda bangsa bisa segera diperbaiki.

\section{METODOLOGI PENELITIAN}

Penelitian ini adalah penelitian lapangan yang menerapkan metode 
kualitatif karena dalam penelitian ini: (1) latar alamiah sebagai sumber data, (2) peneliti adalah instrumen kunci dalam penelitian, (3) penelitian kualitatif lebih mementingkan proes daripada hasil, (4) cedrung menganalisis data secara induktif, dan (5) makna yang dimiliki pelaku yang mendasari tindakan mereka merupakan aspek esensial dalam penelitian (Bogdan dan Biklen, 1982); dan data deskriptif: ucapan atau tulisan dan perilaku yang dapat diamati dari orangorang (subyek) itu sendiri, (Bogdan dan Taylor dalam Furchan, 1992).

Teknik pengumpulan data yang digunakan adalah teknik wawancara tak terstruktur (Bogdan dan Biklen, 1990; dan Jackson, 1995). Pemilihan Informan dilakukan dengan teknik snow-ball sampling berdasarkan sejumlah kriteria, yaitu: memahami latar penelitian, memiliki pengetahuan tentang subyek yang diteliti, dan memiliki perspektif yang berbeda, dapat dipercaya, berada pada posisi mengetahui situasi, dan memainkan peranan yang berbeda dan mempunyai perspektif yang agak berbeda (Moleong, 1988; Miles dan Huberman, 1986; dan, Fraenkel dan Wallen, 1990). Pemilihan informan awal dimulai dari orang berfungsi sebagai gate-keeper dan knowledgeable informant yang berfungsi membuka pintu untuk mengenali keseluruhan medan secara luas, yaitu informan yang berasal dari Dinas Pendidikan Kabupaten Tanah Datar (Faisal, 1990) dan guru-guru bahasa Inggris pada tiga sekolah yang menjadi pilot project implementasi Kurikulum 2013 di Kabupaten Tanah Datar (SMAN 1 dan 2 Batusangkar, SMAN 1 Lintau).

Teknik analisis datayang diterapkan adalah model interaktif (Miles dan Huberman, 1994) yang meliputi proses tiga tahap, yaitu: reduksi data, penyajian data dan penarikan kesimpulan/verifikasi.
Teknik pengecekan keabsahan data yang dilakukan adalah melalui triangulasi sumber, dengan membandingkan data hasil wawancara antara sumber data atau informan yang satu dengan yang lainnya, dan antara hasil wawancara dari sumber yang sama pada waktu yang berlainan (Sugiyono, 2012).

\section{PEMBAHASAN}

\section{Landasan Teori}

\section{Kurikulum 2013}

Mulyasa (2006: 66) menyatakan bahwa kurikulum dapat berarti kurikulum tertulis (written curriculum) atau dokumen kurikulum yang merupakan kurikulum potensial (potencial curriculum) dan bisa juga berarti kurikulum nyata yang yang benar-benar diimplementasikan dalam kegiatan pembelajaran (actual curriculum) atau yang sering disebut curriculum implementation. Berdasarkan Peraturan Pemerintah Nomor 17 Tahun 2010, Pengelolaan dan Penyelenggaraan Pendidikan dasar dan menengah menurut actual curriculum (Kurikulum 2013) bertujuanagar peserta didik berkembang menjadi manusia yang:

1) Beriman dan bertakwa kepada Tuhan Yang Maha Esa, berakhlak mulia, dan berkepribadian luhur;

2) Berilmu, cakap, kritis, kreatif, dan inovatif;

3) Sehat, mandiri, dan percaya diri; dan

4) Toleran, peka sosial, demokratis, dan bertanggung jawab.

Tujuan pendidikan karakter yang merupakan tujuan Kurikulum 2013, adalah: (1) Menguatkan nilai-nilai kehidupan yang dianggap penting dan perlu; (2) Mengoreksi perilaku peserta didik yang tidak bersesuaian dengan nilai-nilai yang dikembangkan oleh sekolah; dan (3) Membangun hubungan 
yang harmonis dengan keluarga dan masyarakat (Darma Kesuma dalam Fadlillah dan Khorida, 2013: 25); (1) Mengembangkan potensi kalbu/nurani/ afektif peserta didik yang memiliki nilainilai karakter; (2) Mengembangkan kebiasaan dan perilaku terpuji peserta didik agar sejalan dengan nilai-nilai universal dan tradisi budaya bangsa yang religius; (3) Menanamkan jiwa kepemimpinan dan tanggung jawab pada peserta didik sebagai generasi penerus bangsa; (4) Mengembangkan kemampuan peserta didik menjadi manusia yang mandiri, kreatif, dan berwawasan kebangsaan; dan (5) Mengembangkan lingkungan kehidupan sekolah sebagai lingkungan belajar yang aman, jujur, penuh kreativitas dan persahabatan dan dengan rasa kebangsaan yang tinggi juga penuh kekuatan (Zubaedi dalam Fadlillah dan Khorida, 2013: 25).

Struktur kurikulum SMA/MA berdasarkan Kurikulum 2013 terdiri atas:

1) Kelompok mata pelajaran wajib yang diikuti oleh seluruh peserta didik.

2) Kelompok mata pelajaran peminatan yang diikuti oleh peserta didik sesuai dengan bakat, minat, dan kemampuannya.

3) Untuk MA dapat menambah dengan mata pelajaran kelompok peminatan keagamaan.

Struktur kelompok mata pelajaran wajib dalam kurikulum SMA/MA adalah sebagai berikut:

\begin{tabular}{|c|c|c|c|c|}
\hline \multirow{2}{*}{\multicolumn{2}{|c|}{ MATA PELAJARAN }} & \multicolumn{3}{|c|}{$\begin{array}{l}\text { ALOKASI WAKTU } \\
\text { BELAJAR } \\
\text { PER MINGGU }\end{array}$} \\
\hline & & $\mathbf{x}$ & XI & XII \\
\hline \multicolumn{5}{|c|}{ Kelompok A (Wajib) } \\
\hline 1. & Pendidikan Agama dan Budi Pekerti & 3 & 3 & 3 \\
\hline 2. & Pendidikan Pancasila dan Kewarganegaraan & 2 & 2 & 2 \\
\hline 3. & Bahasa Indonesia & 4 & 4 & 4 \\
\hline 4. & Matematika & 4 & 4 & 4 \\
\hline 5. & Sejarah Indonesia & 2 & 2 & 2 \\
\hline 6. & Bahasa Inggris & 2 & 2 & 2 \\
\hline \multicolumn{5}{|c|}{ Kelompok B (Wajib) } \\
\hline 7. & Seni Budaya & 2 & 2 & 2 \\
\hline 8. & Pendidikan Jasmani, Olah Raga, dan Kesehatan & 3 & 3 & 3 \\
\hline 9. & Prakarya dan Kewirausahaan & 2 & 2 & 2 \\
\hline \multicolumn{2}{|r|}{ Jumlah Jam Pelajaran Kelompok A dan B per Minggu } & 24 & 24 & 24 \\
\hline \multicolumn{5}{|c|}{ Kelompok C (Peminatan) } \\
\hline \multicolumn{2}{|r|}{ Mata Pelajaran Peminatan Akademik (SMA/MA) } & 18 & 20 & 20 \\
\hline \multicolumn{2}{|r|}{ Jumlah Jam Pelajaran yang Harus Ditempuh per Minggu } & 42 & 44 & 44 \\
\hline
\end{tabular}

(Sumber: Download Kurikulum 2013 untuk SMA/MA danhttp://id.wikipedia. org/ wiki/ Kurikulum 2013, diunduh Jumat 9 Mei 2014)

\section{Peranan Guru Berdasarkan Kurikulum 2013}

Untuk menghasilkan generasi muda yang lebih berkualitas dan ber- karakter, sejumlah perubahan dilakukan dalam kurikulum 2013, antara lain dalam proses pembelajaran, jumlah mata pelajaran dan jumlah jam pelajaran. Ber- 
kaitan dengan perubahan ini, tentu terjadi pula perubahan dalam peranan guru. Dalam kurikulum ini, peran guru menjadi sangat penting demi terlahirnya generasi muda Indonesia yang lebih berkarakter dan berkualitas. Tidak dapat dipungkiri bahwa guru masa kini bekerja dalam dunia yang berubah dengan cepat. Oleh sebab itu, guru harus menjadi bagian dari perubahan dan perkembangan ilmu pengetahuan dan teknologi guru harus menjadi mitra teknologi dan menerapkan dalam dunia pembelajaran. Guru masa kini harus bekerja bersama untuk menfasilitasi, berinovasi, menterpadukan, mengkoordinasikan, berpartisipasi, menemukan, mengadvokasi, memberi petunjuk jalan (B.A. dalam http://www.unpak.ac.id/index.php/15news/91-seminar-nasionalimplementasi-kurikulum-2013-gurusekolah-dasar).

Sanjaya (2008, h. 21-31) mengemukakan peran guru dalam proses pembelajaran, yaitu guru sebagai: 1) sumber belajar, 2) fasilitator, 3) pengelola, 4) demonstrator, 5) pembimbing, 6) motivator, dan 7) evaluator. Lebih jauh Hamalik (2006, h. 128-130) menyatakan bahwa tanggung jawab guru meliputi:

1) Guru harus menuntun murid-murid belajar, 2) Turut serta membina kurikulum sekolah, 3) Melakukan pembinaan terhadap diri siswa (kepribadian, watak, dan jasmaniah), 4) Memberikan bimbingan kepada murid, 5) Melakukan diagnosis atas kesulitan-kesulitan belajar dan mengadakan penilaian atas kemajuan belajar, dan 6) Menyelenggarakan penelitian.

Dari pendapat di atas dapat disimpulkan bahwa guru memiliki peranan yang sangat kompleks dan strategis demi terwujudnya peserta didik yang berkarakter.

\section{Permasalahan dalam Mengimplemen- tasikan Kurikulum 2013}

Implementasi adalah suatu proses penerapan ide konsep, kebijakan atau inovasi dalam suatu tindakan praktis sehingga memberikan dampak dalam bentuk perubahan pengetahuan, keterampilan maupun nilai dan sikap (Mulyasa, 2006: 93). Lebih jauh, implementasi kurikulum dapat diartikan sebagai suatu proses penerapan ide konsep, kebijakan atau inovasi kurikulum sehingga memberikan dampak positif terhadap peserta didik dalam bentuk perubahan pengetahuan, keterampilan maupun nilai dan sikap. Dengan kata lain, bagaimana sebuah written curriculum diaktualisasikan dalam bentuk pembelajaran. Dengan demikian, Implementasi Kurikulum Berbasis Karakter dapat diartikan sebagai suatu proses penerapan ide konsep, kebijakan atau inovasi kurikulum sehingga memberikan dampak positif terhadap perubahan karakter peserta didik.

Hariyadi dan Halide mengatakan bahwa penerapan Kurikulum 2013 pada 2014 dinilai terlalu dipaksakan karena guru yang ada di Kota Makassar, sebagai contohnya, belum menerima pelatihan terkait dengan penerapan kurikulum tersebut dan belum adanya buku yang akan digunakan. Lebih lanjut Halide mengimbau pemerintah menunda penerapan kurikulum dimaksud agar bisa melengkapi segala kekurangan terlebih dulu karena pelaksanaan kurikulum harus didahului dengan uji coba (http://www.tempo.co/read/news/2014/0 3/13/079561946/Penerapan-Kurikulum2013-Terlalu-Dipaksakan, diunduh pada Jumat 9 Mei 2014).

Hal senada tentang pemaksaan implelementasi kurikulum 2013 juga mengemukakan dalam raker komisi $\mathrm{X}$ dengan Kementerian Pendidikan dan Kebudayaan (Kemendikbud). Mayoritas 
anggota Komisi $\mathrm{X}$ mengkritik pendampingan yang diberikan oleh Kemendikbud terhadap para guru terkait implementasi kurikulum ke peserta didik hingga buku ajar. Secara khusus, Itet Tridjajati Sumarjianto -anggota Fraksi PDI-P- menilai perlu adanya pendampingan dan pelatihan berkelanjutan terhadap para tenaga pendidik itu. Rohmani justru menyoroti buku ajar dalam kurikulum 2013 di mana ada subtansi buku ajar kurikulum baru itu yang salah http://kampus.okezone.com/read/2014/0 3/04/560/950003/kurikulum-2013-dariguru-hingga-buku-ajar/largeyang diunduh pada Jumat, 9 Mei 2014.

Dalam Berita Utama Padang Ekspres dengan judul "Guru Bingung Belum Ada Buku Pegangan", terbitan Selasa 20 Mei 2014 terungkap bahwa pelatihan guru untuk implementasi kurikulum baru ini berjenjang. Di samping itu juga terungkap bahwa guru bingung karena selama pelatihan mereka tidak memegang buku bahan ajar. Dalam sebuah artikel yang berjudul "Kurikulum 2013 Terkendala SDM" dalam kolom Metropolis Koran Padang ekspres yang terbit pada Selasa 27 Mei 2014, Dinas Pendidikan Padang mengaku bahwa implementasi Kurikulum 2013 terken-dala SDM, buku panduan dan fasilitas pendukung lainnya.

Hal senada juga disampaikan oleh Itje Chodijah -Ketua Dewan Pertimbangan Federasi Serikat Guru Indonesia (FSGI)- yang mengatakan bahwa penerapan Kurikulum 2013 hanya sekadar formalitas karena persiapan Kementerian Pendidikan dan Kebudayaan dalam menerapkan kurikulum tersebut di semua sekolah sangat minim. Menurutnya ada sejumlah permasalahan terkait dengan penerapan kurikulum tersebut, yaitu: proses penyusunan desainnya dinilai tidak transparan, uji publik juga dinilai asal-asalan serta minimnya sosialisasi, tidak adanya koordinasi yang baik antara desain awal dengan tim teknis, baik untuk buku cetak maupun sistem evaluasi, banyaknya sekolah tidak memiliki buku panduan penerapan Kurikulum 2013 walaupun sudah ditunjuk mengimplementasikan kurikulum tersebut, masalah penilaian dan pengisian buku rapor, dan tidak konsistennya Kementerian Pendidikan dan Kebudayaan yang menurunkan target implementasi, yang semula 30 persen dari total sekolah menjadi hanya 2 persen (6.213 sekolah), dan terlambatnya buku diktat dan buku teks dicetak dan didistribusikan ke sekolahsekolah sehingga berdampak pada penundaan pelatihan guru.

(http://edukasi.kompas.com /read/ 2014/01/02/ 1611598/ Pene-rapan. Kurikulum.2013.Hanya.

Sekadar.Formalitas (diunduh Jumat 9 Mei 2014)

\section{Hasil Penelitian}

Hasil penelitian menunjukkkan bahwa ada 16 jenis permasalahan yang dihadapi oleh guru Bahasa Inggris SLTA Kabupaten Tanah Datar dalam mengimplementasikan Kurikulum 2013, yaitu:

a. Guru belum Mendapatkan Pelatihan Kurtilas secara Memadai;

b. Belum Tersedianya Buku Sumber untuk Guru dan Siswa;

c. Ketersediaan Sarana \& Prasaran yang belum Memadai;

d. Belum Terampilnya Guru-guru dalam Memanfaatkan Informantion Techno$\log y(\mathrm{IT})$;

e. Guru Kesulitan Menyusun RPP berbasis Kurikulum 2013;

f. Guru Mengalami Kesulitan dalam Melaksanakan Penilaian berbasis Kurikulum 2013;

g. Belum Tersedianya Juknis Penilaian berbasis Kurikulum 2013;

h. Guru mengalami kesulitan dalam mengubah cara belajar siswa yang pasif;

i. Guru mengalami kesulitan dalam menerapkan lima langkah metode ilmiah $(5 \mathrm{M})$ 
j. Guru belum memiliki Pentunjuk Teknis tentang model dan cara pelaporan hasil belajar siswa berbasis Kurikulum 2013;

k. Ada guru yang kekurangan "lahan" karena tidak dibukanya Peminatan Bahasa pada kebanyakan sekolah;

1. Kurangnya jam yang disediakan untuk mencapai persyaratan yang ditetapkan;

m. Kurangnya keterampilan guru dalam memilih dan menggunakan media pembelajaran;

n. Belum tersedianya petunjuk tentang cara pembagian materi pelajaran per semester;

o. Guru kesulitan untuk melatih siswa dalam menggunakan High Order Thinking Skills (HOTS); dan

p. Belum terencananya program matrikulasi bagi Peserta Didik.

Dari temuan penelitian di atas, permasalahan-permasalahan tersebut dapat dikelompokkan menjadi dua, jika dianalisis dengan seksama, yaitu: permasalahan yang bersumber dari diri guru bahasa Inggris itu sendiri dan yang berasal dari luar diri mereka.

Yang berasal dari guru itu sendiri meliputi: (1) kurangnya keterampilan guru dalam menggunakan IT, (2) guru kurang paham cara menyusun dan (3) membuat RPP, (4) melaksanakan PBM, dan (5) melakukan penilaian (6) kurang memiliki keterampilan guru dalam memilih dan menggunakan media pembelajaran berbasis Kurtilas.

Permasalahan-permasalahan lainnya justeru berasal dari luar diri guru itu sendiri dan terkait dengan kesiapan pemerintah, yang meliputi: pelatihan tentang kurikulum baru itu yang sangat tidak memadai, Didit Hariyadi dan Halide mengatakan bahwa penerapan Kurikulum 2013 pada 2014 dinilai terlalu dipaksakan karena guru yang ada di Kota Makassar, sebagai contohnya, be- lum menerima pelatihan terkait dengan penerapan kurikulum tersebut dan belum adanya buku yang akan digunakan. Lebih lanjut Halide mengimbau pemerintah menunda penerapan kurikulum dimaksud agar bisa melengkapi segala kekurangan terlebih dulu karena pelaksanaan kurikulum harus didahului dengan uji coba

http://www.tempo.co/read/ news/ 2014/ 03/ 13/ 079561946/ PenerapanKurikulum-2013-Terlalu-Dipaksakan, diunduh pada Jumat 9 Mei 2014).

Permasalahan kedua adalah belum adanya buku sumber sementara guru sudah diwajibkan menerapkan kurikulum tersebut. Permasalahan ini juga telah menjadi sorotan anggota dewan dalam rapat komisi $\mathrm{X}$ dengan Kementerian Pendidikan dan Kebudayaan (Kemendikbud). Mayoritas anggota Komisi X mengkritik pendampingan yang diberikan oleh Kemendikbud terhadap para guru terkait implementasi kurikulum ke peserta didik hingga buku ajar. Secara khusus, Itet Tridjajati Sumarjianto -anggota Fraksi PDI-P- menilai perlu adanya pendampingan dan pelatihan berkelanjutan terhadap para tenaga pendidik itu. Rohmani justru menyoroti buku ajar dalam kurikulum 2013 di mana ada subtansi buku ajar kurikulum baru itu yang salah.

http://kampus.okezone.com/read/2014/0 3/04/560/ 950003/kurikulum-2013-dariguru-hingga-buku-ajar/large yang diunduh pada Jumat, 9 Mei 2014.

Berita miring senada diekspos dalam dalam Berita Utama Padang Ekspres dengan judul "Guru Bingung Belum Ada Buku Pegangan", terbitan Selasa 20 Mei 2014 terungkap bahwa pelatihan guru untuk implementasi kurikulum baru ini berjenjang. Di samping itu juga terungkap bahwa guru bingung karena selama pelatihan mereka tidak memegang buku bahan ajar. Dalam 
sebuah artikel yang berjudul "Kurikulum 2013 Terkendala SDM" dalam kolom Metropolis Koran Padang ekspres yang terbit pada Selasa 27 Mei 2014, Dinas Pendidikan Padang mengaku bahwa implementasi Kurikulum 2013 terkendala SDM, buku panduan dan fasilitas pendukung lainnya.

Permasalahan-permasalahan selanjutnya yang ditemukan dan juga telah dikhawatirkan banyak pihak adalah kurangnya persiapan bagi implementasi kulikulum baru tersebut, yang meliputi: kurangnya sarana-prasarana pendukung, belum tersedianya juknis penilaian hasil belajar peserta didik, belum tersedianya juknis untuk cara dan model pelaporan hasil belajar peserta didik, belum adanya panduan pembagian materi pelajaran per semester, dan belum adanya pedoman untuk program matrikulasi. Itje Chodijah -Ketua Dewan Pertimbangan Federasi Serikat Guru Indonesia (FSGI)- yang mengatakan bahwa penerapan Kurikulum 2013 hanya sekadar formalitas karena persiapan Kementerian Pendidikan dan Kebudayaan dalam menerapkan kurikulum tersebut di semua sekolah sangat minim. Menurutnya ada sejumlah permasalahan terkait dengan penerapan kurikulum tersebut, yaitu: proses penyusunan desainnya dinilai tidak transparan, uji publik juga dinilai asal-asalan serta minimnya sosialisasi, tidak adanya koordinasi yang baik antara desain awal dengan tim teknis, baik untuk buku cetak maupun sistem evaluasi, banyaknya sekolah tidak memiliki buku panduan penerapan Kurikulum 2013 walaupun sudah ditunjuk mengimplementasikan kurikulum tersebut, masalah penilaian dan pengisian buku rapor, dan tidak konsistennya Kementerian Pendidikan dan Kebudayaan yang menurunkan target implementasi, yang semula 30 persen dari total sekolah menjadi hanya 2 persen (6.213 sekolah), dan terlambatnya buku diktat dan buku teks dicetak dan didistribusikan ke sekolah-sekolah se- hingga berdampak pada penundaan pelatihan guru.

(http://edukasi.kompas.com /read/ 2014/ 01/ 02/1611598/Penerapan. Kurikulum. 2013.Hanya. Sekadar. Formalitas (diunduh Jumat 9 Mei 2014).

Dua permasalahan berikutnya, yaitu: banyak peserta didik banyak yang tidak mandiri, dan belum terbiasa menggunakan HOTS, bisa muncul karena karakter peserta didik itu sendiri dan sitem pendidikan yang telah mereka jalani. Dalam hal ini, mau tidak mau, orang tua, pihak sekolah dan pemerintah, tentu memegang andil yang besar.

Permasalahan tidak dibukanya peminatan bahasa pada banyak sekolah akan terjadi apabila pihak sekolah, khususnya Kepala Sekolah kurang paham dan kurang cermat membaca peraturan yang telah digariskan oleh pemerintah.

Permasalahan lainnya yaitu kurangnya target waktu yang diberikan tentu merupakan permasalahan yang perlu dibahas secara bersama antara praktisi (guru bahasa Inggris) dan pengambil kebijakan (pemerintah). Tanpa adanya pembahasan yang cermat tentang kuota jam pelajaran bahasa Inggris ini tentu akan tetap menjadi polemic bagi dunia pendidikan di Indonesia.

\section{PENUTUP}

Dari hasil penelitian dapat disimpulkan bahwa ada dua jenis permasalahan yang dihadapi oleh guru bahasa Inggris di Kabupaten Tanah Datar dalam mengimplementasikan Kurikulum 2013, yaitu permasalahan yang berasal dari dalam diri mereka sendiri dan permasalahan yang berasal dari luar diri mereka sendiri. Permasalahan yang berasal dari guru itu sendiri meliputi: kurangnya keterampilan guru dalam menggunakan IT, sulitnya guru dalam menyusun RPP, terbatasnya kemampuan guru dalam melaksanakan PBM, dan melakukan penilaian, serta kurangnya 
keterampilan guru dalam memilih dan menggunakan media pembelajaran berbasis Kurtilas.

Permasalahan yang berasal dari luar diri mereka sediri meliputi: kurangnya sarana-prasarana pendukung, belum tersedianya juknis penilaian hasil belajar

\section{DAFTAR RUJUKAN}

Abdul Majid dan Dian Andayani. 2010. Pendidikan Karakter dalam Perspektif Islam. Bandung: Zulfa Offset.

Cr3 dalam Padang Ekspres. Guru Bingung Belum Ada Buku Pegangan. Selasa 27 Mei 2014.

Emzir. 2010. Metodologi Penelitian Pendidikan Kuantitatif \& Kualitatif (edii Revisi). Jakarta: PT RadjaGrafindo Persada.

Fadlillah, M dan Khorida, L.M. 2013. Pendidikan Karakter Anak Usia Dini: Konsep dan Aplikasinya dalam PAUD. Jogjakarta: Ar-Ruzz Media.

Gede Raka, dkk. 2011. Pendidikan Karakter di Sekolah dari Gagasan ke Tindakan. Jakarta: PT. Elex Media Komputindo

Hornby. 2000. Oxford Advanced Learner's Dictionary (Sixth Edition). Oxford: Oxford University Press.

http://edukasi.kompas.com/read/2014/01 /02/1611598/Penerapan.

Kurikulum.2013.Hanya.

Sekadar.Formalitas (diunduh Jumat 9 Mei 2014)

http://id.wikipedia.org/wiki/Kurikulum 2013 (Diunduh Jumat 9 Mei 2014)

http://kampus.okezone.com/read/2014/0 3/04/560/950003/kurikulum-2013- peserta didik, belum tersedianya juknis untuk cara dan model pelaporan hasil belajar peserta didik, belum adanya panduan pembagian materi pelajaran per semester, dan belum adanya pedoman untuk program matrikulasi.

dari-guru-hingga-buku-ajar/large (diunduh Jumat 9 Mei 2014)

http://writing-

contest.bisnis.com/artikel/read/201 40401/ 377/ 215082/peningkatankualitas-guru-untukmenyeimbangkan-dengankurikulum-2013-dalammembangun-pendidikan-diindonesia (diunduh pada Jumat 9 Mei 2014)

http://www.tempo.co/read/news/2014/03 /13/079561946/Penerapan-

Kurikulum-2013-TerlaluDipaksakan (diunduh Jumat 9 Mei 2014)

Kemp, Jerrold E. 1985. The Instructional Deign Process. New York: Harper \& Row Publishers.

Khoiriyah, Siti. 2013. The Difficulties Faced by the English Teachers in Applying Character Education in Lesson Plans (A Study of the Eleventh Grade English Teachers of SMAN in Tanah Datar Regency in 2012/2013 Academic Year). Skripsi: Tidak Diterbitkan.

Miles, Mathew. B dan Huberman, A. Michael. 1994. Qualitative Data Analysis. Los Angeles: Sage Publications, Inc.

Muslich, Masnur. 2011. Pendididkan Karakter: Menjawab Tantangan Krisis Multidimensional. Jakarta: Bumi Aksara. 
Putra, Nusa. 2011. Research \& Development, Penelitian dan Pengembangan: Suatu Pengantar. Jakarta: PT RadjaGrafindo Persada.

Richards, Jack. C. 2001. Curriculum Development in Language Teaching. Cambridge: Cambridge University Press.

Richards, Jack. C and Schmidt, Richard. 2002. Longman Dictionary of Language Teaching \& Applied Linguistics (Third Edition). Harlow: Pearson Education Limited.

Samani, M dan Hariyanto. 2013. Pendidikan Karakter. Bandung: PT. Remaja Rosdakarya.

Sofan Amri, dkk. 2011. Implementasi Pendidikan Karakter dalam Pembelajaran. Jakarta: PT. Prestasi Pustakaraya

Sugiyono. 2007. Metode Penelitian Kuantitatif, Kualitatif, dan R \& D. Bandung: Penerbit Alfabeta.

Tomlinson, Brian. 1998. Materials Development in Language Teaching. Cambridge: Cambridge University Press.

Mulyasa, E. 2006. Kurikulum Berbasis Kompetensi: Konsep, Karakter- istik, dan Implementasi. Bandung: PT. Remaja Rosdakarya.

Pramudia, Ade Alfa. 2014. Character Values Implanted by English Teachers in Teaching Process (A Study at SMPs Piloting Curriculum 2013 in Tanah Datar Regency). Skripsi, STAIN Batusangkar (Tidak diterbitkan).

Rosdalia. 2013. Pelaksanaan Pendidikan Karakter oleh Guru PAI di SDN 14 Batipuh Jorong Duo Koto Malalo Pelaksanaan. Skripsi, STAIN Batusangkar (Tidak diterbitkan).

Samani, Muchlis dan Hariyanto. 2013. Konsep dan Model Pendidikan Karakter. Bandung: PT Remaja Rosdakarya.

Sugiyono. 2012. Memahami Penelitian Kualitatif: Dilengkapi Contoh Proposal dan Laporan Penelitian. Bandung: Alfabeta

Usman, Andi. 2014. Pelaksanaan Pendidikan Karakter di MTsN Paninjauan Kecamatan X Koto Kabupaten Tanah Datar. Skripsi, STAIN Batusangkar (Tidak diterbitkan).

Wan dalam Padang Ekspres. Guru Bingung Belum Ada Buku Pegangan. Selasa 20 Mei 2014. 